\title{
Tumor-reactive $\mathbf{T}$ cells are licensed by dendritic cells located in spatially different tissues: implications for dendritic cell vaccines
}

\section{Nadine Santana-Magal, Leen Farhat-Younis and Yaron Carmi}

Since the discovery of dendritic cells (DC), exploiting their unique ability to activate $\mathrm{CD} 4^{+}$and $\mathrm{CD} 8^{+}$ $\mathrm{T}$ cells against cancer cells has held great promise $[1,2]$. Nonetheless, despite countless attempts [3], DC-based vaccines have not yet lived up to expectations [4], beyond preventing tumor growth in prophylactic or adjuvant tumor settings [5, 6] and anecdotal success [7]. It remains unclear why the activation of DC, which are so prominent in activating tumor-reactive $\mathrm{T}$ cells, does not lead to eradication of established solid tumors.

The general wisdom suggests that DC take up tumor antigens at the tumor site and then migrate into the lymph nodes, where they present them to T cell. Since most tumors lack sufficient danger signals that allow DC to present tumor antigens in a stimulatory context, it is not surprising that the corresponding $\mathrm{T}$ cells are often skewed towards regulatory, or anergic phenotype. Consistent with that notion, most DC vaccines are based on stimulating DC ex vivo, followed by their infusion back to the patient. Traditional efforts focused on finding the most potent stimuli to mature and activate DC and on identifying the ideal unique, high-avidity tumor antigens that can be loaded on the DC $[4,8]$. More recently, major efforts have been targeted at locating the most potent DC subset to stimulate reactive T cells [9]. DC are comprised of heterogeneous cell populations that differ from each other in their pattern-recognition receptors, tissue distribution, migratory patterns, and antigen-presentation capabilities $[10,11]$. DC subsets such $\mathrm{CD} 103^{+} / \mathrm{CD} 141^{+}$or $\mathrm{CD}^{+} \mathrm{cDC}$ are superior antigen-presenting cells, whose prevalence in tumors and blood is limited [12-14]. In contrast, MoDC are much more abundant and can be easily matured ex vivo from circulating monocytes [15]. While such efforts improve the prevalence of anti-tumor $\mathrm{T}$ cells in the circulation, eradication of established tumors remains out of reach. One possibility is that tumor-reactive
A
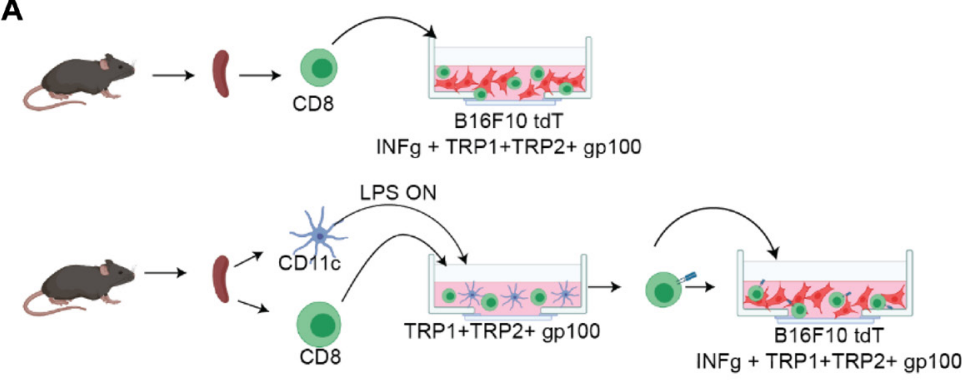

C

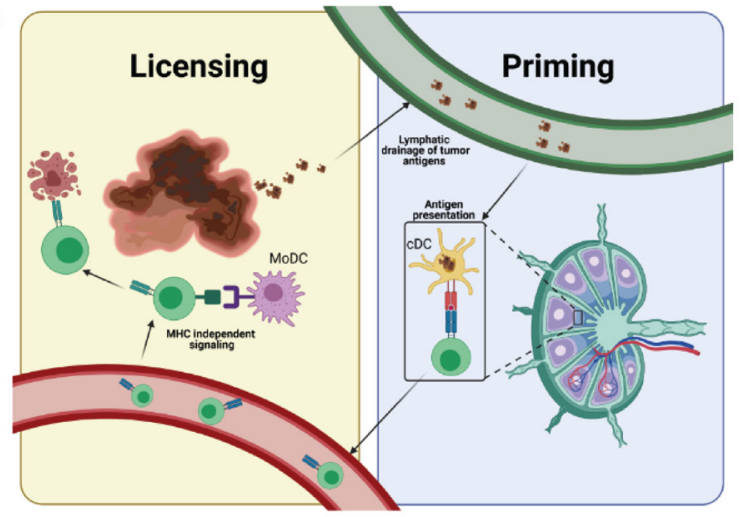

B

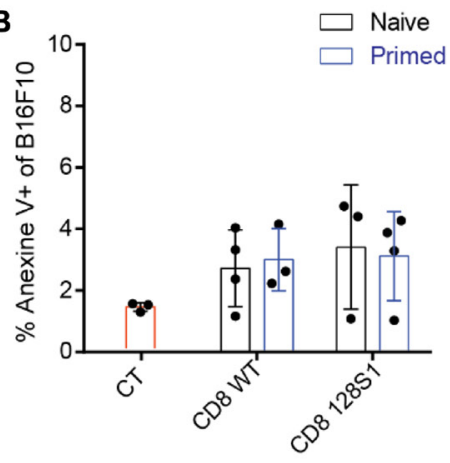

Figure 1: Activation of T cells by LN DC is not sufficient to elicit tumor cell lysis. (A) Experimental design- Splenic CD8 ${ }^{+} \mathrm{T}$ cells are isolated from naïve mice and incubated with IFN $\gamma$-stimulated tumor cells as such, or after incubation with activated LN-derived DC pulsed with tumor antigens. (B) Graph summarizes the percentages of B16F10 cells that express Annexin V following overnight incubation with splenic T cells. (C) Illustration of proposed T cell activation model. Illustrations were created with https://BioRender.com. 
T-cell clones are induced by DC yet are inhibited by the suppressive tumor microenvironment, or by intrinsic changes in tumor cells $[16,17]$.

In a recent paper, Santana-Magal and colleagues studied why once melanoma tumors exceed a certain size in mice, immunotherapies fail to eradicate them, despite the presence of tumor-reactive $\mathrm{T}$ cells in the periphery [18]. Using the photoactivatable Denrdra2 mice, which enable to fluorescently-label cells specifically in the tumors using optical fiber, she found that in contrast to the current paradigm, MoDC do not migrate from the tumor lesion to the draining lymph nodes. While migration of migratory and epidermal DC to the DLN is observed, it only occurs during early tumor onsets, and these cells are almost completely absent from late-stage tumors. At this stage, antigens predominantly reach the DLN trough passive drainage. Most importantly, Santana-Magal and colleagues' work stresses that the main role of tumorinfiltrating DC is not to present tumor antigens, but rather to license the cytotoxic activity of infiltrating $\mathrm{T}$ cells.

To further test that possibility, we isolated $\mathrm{CD} 8^{+}$ $\mathrm{T}$ cells from control mice, tumor-vaccinated mice, or allogeneic mice and incubated them for three to four days with LPS-activated LN DC pulsed with a mixture of known melanoma antigens. Next, we isolated the T cells and incubated them with melanoma cells pre-activated with IFN $\gamma$ and pulsed with the same MHC-I antigens used for priming (experimental design is illustrated in Figure 1A). Importantly, none of the primed $\mathrm{T}$ cells was capable of inducing melanoma cell killing (Figure 1B). However, the addition of MoDC to that co-culture induced a four-fivefold enhancement of the killing capacity of primed $\mathrm{T}$ cells, in an MHC-I independent manner (not shown). This simple experiment strongly supports the argument that a single signal, as potent as it may be, delivered by LN DC is not sufficient to overcome the intrinsic activation threshold to elicit the cytotoxic activity of $\mathrm{T}$ cells.

Over the past decade, a number of seminal studies demonstrated that TCR-MHC is more promiscuous than earlier thought, allowing each $\mathrm{T}$ cell to recognize several to hundreds of different peptides [19-21]. One potential consequence of these models is that licensing T cells to act in the lymph node will result in off-site cytotoxicity, or the lysing of antigen-presenting cells expressing similar antigens. The T-cell activation model suggested by Santana-Magal and colleagues (illustrated in Figure 1C) provides a different insight to the limited clinical benefit of DC vaccines and a simple explanation as to why LN DCs are not killed by their corresponding activated T cells. Consistent with previous publications emphasizing the spatial elements involved in induction of tumor immunity [15], we believe that potent DC vaccines must account for the need to stimulate the various DC subsets located at both the LN and tumor sites. One such approach was recently published by Ackerman and colleagues, utilizing tumor-binding antibodies coupled with a stimulatory agent. It may be that such a procedure, possibly in combination with the blocking of suppressor receptors on $\mathrm{T}$ cells, would elicit the full cytotoxic potential of infiltrating tumor-reactive $\mathrm{T}$ cells.

\section{CONFLICTS OF INTEREST}

Authors have no conflicts of interest to declare.

Yaron Carmi: Department of Pathology, Sackler School of Medicine, Tel-Aviv University, Israel

Correspondence to: Yaron Carmi, email yaron.carmi@gmail.com

Keywords: dendritic cells, antigen presentation, T cells

Received: March 03, 2021

Published: August 03, 2021

\section{REFERENCES}

1. Steinman RM, et al. Nature. 2007; 449:419-26. https://doi. org/10.1038/nature06175. [PubMed]

2. Joffre OP, et al. Nat Rev Immunol. 2012; 12:557-69. https:// doi.org/10.1038/nri3254. [PubMed]

3. Palucka K, et al. Immunity. 2013; 39:38-48. https://doi. org/10.1016/j.immuni.2013.07.004. [PubMed]

4. Bol KF, et al. Clin Cancer Res. 2016; 22:1897-906. https:// doi.org/10.1158/1078-0432.ccr-15-1399. [ [PubMed]

5. Ott PA, et al. Nature. 2017; 547:217-21. https://doi. org/10.1038/nature22991. [PubMed]

6. Sahin U, et al. Nature. 2017; 547:222-26. https://doi. org/10.1038/nature23003. [PubMed]

7. Hsu FJ, et al. Nat Med. 1996; 2:52-58. https://doi. org/10.1038/nm0196-52. [PubMed]

8. Palucka K, et al. Nat Rev Cancer. 2012; 12:265-77. https:// doi.org/10.1038/nrc3258. [PubMed]

9. Wimmers F, et al. Front Immunol. 2014; 5:165. https://doi. org/10.3389/fimmu.2014.00165. [PubMed]

10. Mildner A, et al. Immunity. 2014; 40:642-56. https://doi. org/10.1016/j.immuni.2014.04.016. [PubMed]

11. Merad M, et al. Annu Rev Immunol. 2013; 31:563-604. https://doi.org/10.1146/annurev-immunol-020711-074950. [PubMed]

12. Guilliams M, et al. Immunity. 2016; 45:669-84. https://doi. org/10.1016/j.immuni.2016.08.015. [PubMed]

13. Salmon H, et al. Immunity. 2016; 44:924-38. https://doi. org/10.1016/j.immuni.2016.03.012. [PubMed]

14. Roberts EW, et al. Cancer Cell. 2016; 30:324-36. https:// doi.org/10.1016/j.ccell.2016.06.003. [PubMed] 
15. Spitzer MH, et al. Cell. 2017; 168:487-502.e15. https://doi. org/10.1016/j.cell.2016.12.022. [ [ $\underline{\text { PubMed] }}$

16. Joyce JA, et al. Science. 2015; 348:74-80. https://doi. org/10.1126/science.aaa6204. [PubMed]

17. Wculek SK, et al. Nat Rev Immunol. 2020; 20:7-24. https:// doi.org/10.1038/s41577-019-0210-z. [PubMed]

18. Santana-Magal N, et al. Cancer Res. 2020; 80:1942-56. https://doi.org/10.1158/0008-5472.can-19-2944. [PubMed]

19. Birnbaum ME, et al. Cell. 2014; 157:1073-87. https://doi. org/10.1016/j.cell.2014.03.047. [PubMed]

20. Wooldridge L, et al. J Biol Chem. 2012; 287:1168-77. https://doi.org/10.1074/jbc.m111.289488. [PubMed]

21. Bentzen AK, et al. Nat Biotechnol. 2018. https://doi. org/10.1038/nbt.4303. [PubMed]
Copyright: $@ 2021$ Santana-Magal et al. This is an open access article distributed under the terms of the Creative Commons Attribution License (CC BY 3.0), which permits unrestricted use, distribution, and reproduction in any medium, provided the original author and source are credited. 